\title{
Electrical Activity and Calcium Influx Regulate Ion Channel Development in Embryonic Xenopus Skeletal Muscle
}

\author{
Paul Linsdell and William J. Moody \\ Department of Zoology, University of Washington, Seattle, Washington 98195
}

\begin{abstract}
The development of electrical excitability involves complex coordinated changes in ion channel activity. Part of this coordination appears to be due to the fact that the expression of some channels is dependent on electrical activity mediated by other channel types. For example, we have previously shown that normal potassium current development in embryonic skeletal muscle cells of the frog Xenopus laevis is dependent on sodium channel activity. To examine the interrelationships between the development of different ionic currents, we have made a detailed study of electrical development in cultured Xenopus myocytes using whole-cell patch-clamp recording. The initial expression of potassium, sodium, and calcium currents is followed by a brief period during which the densities of potassium currents decrease, while at the same time sodium and calcium current densities continue to increase, which may increase electrical excitability during this time. The normal developmental increase in both potassium and sodium currents is inhibited by the sodium channel blocker tetrodotoxin, suggesting that electrical activity normally stimulates the expression of both these currents. These effects of electrical activity appear to be mediated via activation of voltage-gated calcium channels. We suggest that the developmental acquisition of sodium and calcium channels by these cells, possibly coupled with a transient decrease in potassium current density, lead to an increase in electrical excitability and calcium entry, and that this calcium entry provides a critical developmental cue controlling the subsequent development of mature electrical properties.
\end{abstract}

[Key words: Xenopus embryo, ion channels, muscle development, electrical activity, activity-dependent expression, second messengers]

The development of electrical excitability in muscle cells and neurons is characterized by temporally stereotyped changes in the types, densities, and properties of voltage-gated ion channels present (Moody et al., 1991; Spitzer, 1991; Ribera and Spitzer, 1992; Spruce and Moody, 1992; Broadie and Bate, 1993). These characteristic patterns of channel development suggest that they underlie developmentally critical changes in electrical excitabil-

Received Oct. 24, 1994: revised Dec. 13, 1994; accepted Jan. 4, 1995

We thank Julic Coombs-Hahn, Julia Dallman, and Anna Davis for careful reading of the manuscript. This work was supported by NIH Grant HD17486 to W.J.M.

Correspondence should be addressed to Dr. Paul Linsdell, Department of Physiology. McGill University, 3655 Drummond Street, Montreal, Quebec, Canada $\mathrm{H} 361$ \% 1 .

Copyright $\bigcirc 1995$ Society for Neuroscience $0270-6474 / 95 / 154507-08 \$ 05.00 / 0$ ity. This is supported by the finding that normal development is disrupted by altering the time at which different ion channels appear (Jones and Ribera, 1994; Linsdell and Moody, 1994) or the activity of channels already present (Bixby and Spitzer, 1984; Holliday and Spitzer, 1990; Linsdell and Moody, 1994).

Changes in electrical activity influence the expression of a number of different skeletal muscle proteins. For example, electrical activity has been shown to have a direct effect on the expression of muscle nicotinic acetylcholine receptor $\alpha, \beta, \gamma$ and $\delta$ subunits (Klarsfeld and Changeux, 1985; Goldman et al.. 1988), sodium channels (Sherman and Catterall, 1984), chloride channels (Heathcote, 1989), calcium channels (Freud-Silverberg and Shainberg, 1993), myosin (Brevet et al., 1976), acetylcholinesterase (Rubin, 1985), and the cell adhesion molecules $\mathrm{N}$-cadherin (I Iahn and Covault, 1992) and NCAM (Lyles et al., 1993), as well as several members of the basic-helix-loop-helix family of muscle-specific transcription factors (Eftimie et al, 1991; Buonanno et al., 1992; Neville et al., 1992; Chahine et al., 1993; Huang et al., 1993). The link between electrical activity and muscle properties has been suggested to involve changes in protein kinase C activity (Fontaine et al., 1987; Klarsfeld et al., 1989; Huang et al., 1992, 1993), intracellular cyclic AMP (cAMP; Sherman et al., 1985; Offord and Catterall, 1989; Chahine et al., 1993), and intracellular calcium (Sherman and Catterall, 1984; Rubin, 1985; Klarsfeld et al., 1989; Offord \& Catterall, 1989; Hahn and Covault, 1992).

Since electrical activity plays such a key role in controlling muscle properties, we have examined in detail the developmental profiles of different voltage-gated ionic currents that control electrical excitability during muscle development in the frog. Xenopus laevis. We have also studied the effects of electrical activity on the development of these different currents by pharmacologically blocking activity in myocytes developing in culture.

We previously described the earliest developmental appearance of voltage-gated potassium and sodium currents in cultured embryonic Xenopus skeletal muscle cells (Spruce and Moody, 1992; Linsdell and Moody, 1994). These studies have emphasized the functional importance of the fact that these cells always acquire potassium currents earlier in development than sodium currents; reversing the developmental sequence by misexpression of cloned sodium channcls causcd a compensatory upregulation of potassium current density. Here, we describe the later development of voltage-gated currents in these cells. Although the overall trend is an increase in current density during development, we have identified a brief period (approximately $4 \mathrm{hr}$ ) during which the densities of both sustained outward and inwardly rectifying potassium currents decrease, while sodium and 
calcium current densities continue to increase. We find that subsequent increases in potassium and sodium current densities are inhibited by the sodium channel blocker tetrodotoxin (TTX), suggesting that the later development of multiple channel types are stimulated by electrical activity. These effects of electrical activity appear to be mediated via calcium influx through voltage-gated calcium channels, since the effects of TTX are mimicked by the calcium channel blocker nifedipine. We suggest that the acquisition of functional sodium and calcium channels by these cells, possibly coupled with a transient decrease in potassium current density, leads to an increase in electrical activity and calcium entry, which is an important signal in subsequent ion channel development.

\section{Materials and Methods}

Preparation of embryos and muscle cells. Fertilization and culture of Xenopus laevis embryos, and aneural culture of dissociated myocytes were carried out as described previously (Linsdell and Moody, 1994). Briefly, mature eggs were fertilized in vitro and embryos cultured in $10 \%$ Modified Barth's Solution $(8.8 \mathrm{~mm} \mathrm{NaCl}, 0.1 \mathrm{~mm} \mathrm{KCl}, 0.24 \mathrm{~mm}$ $\mathrm{NaHCO}_{3}, 0.082 \mathrm{~mm} \mathrm{MgSO}_{4}, 0.033 \mathrm{~mm} \mathrm{Ca}\left(\mathrm{NO}_{3}\right)_{2}, 0.041 \mathrm{~mm} \mathrm{CaCl}, 1$ mM HEPES, pH 7.4). Embryos were staged according to Nieuwkoop and Faber (1967) and dissected at the early neural fold stage (stage 15; approximately $18 \mathrm{hr}$ after fertilization), the earliest stage at which skeletal muscle cells can be uniquely identified. Dissociated myocytes were plated onto tissue culture plastic dishes (Falcon 3001; Becton Dickinson, Oxnard, CA) containing Danilchik's medium (Keller et al., 1985 $53 \mathrm{~mm} \mathrm{NaCl}, 27 \mathrm{~mm}$ Na.isothionate, $15 \mathrm{~mm} \mathrm{NaHCO}, 4.5 \mathrm{~mm}$ K.gluconate, I $\mathrm{mm} \mathrm{MgSO}, 1 \mathrm{~mm} \mathrm{CaCl}, \mathrm{pH} 8.3$ ).

Culture of muscle cells. Muscle cells were cultured in Danilchik's medium (see above) at room temperature $\left(20-23^{\circ} \mathrm{C}\right.$ ). Where the effects of other factors on muscle cell development were examined, these factors were added to the culture medium immediately prior to cell plating. Apart from TTX, which was usually still present during electrophysiological recordings, these factors were removed $30-90 \mathrm{~min}$ before recording in an attempt to preclude any direct effects on ion channel aclivily. This was achieved by washing the cultures thoroughly with Danilchik's medium. Because some of the factors used to treat cultures are light sensitive, all muscle cultures were kept in the dark until just before recording.

Chemicals. Those factors added to the normal culture medium were TTX $(1 \mu \mathrm{M})$, nifedipine $(10 \mu \mathrm{M})$, and dantrolene (sodium salt; $50 \mu \mathrm{M}$ ). All were obtained from Sigma (St. Louis, MO) and stored frozen as stock solutions until required. Stock solutions were $10 \mu \mathrm{M}$ TTX (in Danilchik's medium), $10 \mathrm{~mm}$ nifedipine (in dimethyl sulfoxide; DMSO, Sigma), and $50 \mathrm{~mm}$ dantrolene (in methanol; Sigma). The maximum concentration of DMSO or methanol in the final culture medium was $0.1 \%$; at this concentration, neither vehicle alone had any effect on the expression of voltage-gated currents. None of the treatments appeared to affect cell survival or morphology, nor did they have any significant effect on mean cell capacilance. The concentrations of TTX and nifedipine used have been shown to block sodium and calcium currents in adult frog muscle; we have independently found that these concentrations effectively abolish voltage-dependent sodium and calcium currents in our cultured muscle cells. Although we were unable to directly test the effect of dantrolene on calcium release from internal stores, the concentration used $(50 \mu \mathrm{M})$ would be expected to produce a maximum effect in adult frog muscle (e.g., Morgan and Bryant, 1977).

Electrophysiological recordings. All recordings were made using the patch-clamp technique in the whole-cell configuration (Hamill et al., 1981). Pipettes were fabricated from glass capillaries (VWR, West Chester, PA) using a two-stage puller (Narishige, Tokyo, Japan), and had resistances of $1-3 \mathrm{M} \Omega$ when filled with recording solutions (see below). Currents were recorded using an EPC-7 amplifier (List, Darmstadt, Germany), filtered at $1 \mathrm{kHz}$ using an eight-pole Bessel filter, and digitized at $2-33 \mathrm{kHz}$ using pCLAMP software (Axon Instruments, Foster City, CA). Voltage errors due to series resistance were compensated electronically; typically $60-90 \%$ compensation was possible. During recordings, the external solution was Danilchik's medium (see above) and the pipette solution contained $80 \mathrm{mM} \mathrm{K} \cdot$ aspartate, $10 \mathrm{mM} \mathrm{KCl}, 10 \mathrm{~mm}$ $\mathrm{NaCl}, 2 \mathrm{mM} \mathrm{MgCl}, 2 \mathrm{~mm}$ EGTA, $3 \mathrm{mM}$ glucose, $2 \mathrm{~mm}$ theophylline, $2 \mathrm{~mm} \mathrm{Mg}$.ATP, $0.1 \mathrm{~mm}$ cAMP, $10 \mathrm{~mm}$ HEPES, pH 7.4.
To record currents through calcium channels, the extracellular solution was replaced with one containing $120 \mathrm{~mm} \mathrm{NaCl}, 5 \mathrm{~mm} \mathrm{KCl}, 10$ $\mathrm{mM} \mathrm{BaCl}, 2$ mM $\mathrm{MgCl}_{2}, 10 \mathrm{~mm}$ HEPES, $1 \mu \mathrm{M}$ TTX. pH 7.4 just before recording. Potassium in the pipette solution was replaced with cesium to block potassium currents. Since under these conditions. current through calcium channels (actually carried by barium) could be recordcd in isolation, a $\mathrm{P} / 4$ leak subtraction protocol could be used to allow more accurate measurement of very small barium currents.

All recordings were made at room temperature $\left(20-23^{\circ} \mathrm{C}\right)$

Data analysis. Identification and measurement of the different voltage-gated currents expressed in these cells, following subtraction of linear leak currents, were as described previously (Spruce and Moody 1992; Linsdell and Moody, 1994), except where described above. Data in Figures 2 and 6 have been corrected for a junction potential of -8 $\mathrm{mV}$ that exists between the pipette solution and Danilchik's medium (Spruce and Moody, 1992). Where mean values are given, they are expressed as mean \pm SEM. All ages of muscle cells quoted are relative to stage 15 .

\section{Results}

\section{Development of voltage-gated currents}

Our previous studies concentrated on the development of voltage-gated potassium and sodium currents in embryonic Xenopus myocytes during the first $10 \mathrm{hr}$ after stage 15 (Spruce and Moody, 1992; Linsdell and Moody, 1994). Here, we describe the later developmental time courses of these currents, up to 30 hr after stage 15. We have also examined the time course of calcium current development for the first time.

At stage 15, the earliest time examined, these cells usually exhibit no voltage-gated currents in response to either depolarization or hyperpolarization. A sustained outward potassium current $\left(I_{\mathrm{K}}\right)$ appears in most cells $2-4 \mathrm{hr}$ after stage 15 , and its density increases steadily until $14 \mathrm{hr}$ (Figs. 1, $2 A$ ). Between 14 and $18 \mathrm{hr}$, however, $I_{\mathrm{K}}$ density decreases significantly $(p<0.01$; one-tailed $t$ test), before again increasing between 18 and $30 \mathrm{hr}$. At early times, the activation kinetics of $I_{\mathrm{K}}$ change, slowing dramatically between 4 and $6 \mathrm{hr}$ (Fig. 1; Linsdell and Moody, 1994). We do not know if this represents a change in the properties of a single type of channel (e.g., Ribera and Spitzer, 1991) or the addition of a more slowly activating type of channel. At later times, the activation kinetics of $I_{K}$ are difficult to observe, due to the addition of a rapidly activating, transient outward current (Fig. 1; see below). The voltage dependence of activation of $I_{\mathrm{K}}$ does change during development, with the threshold of activation being about $20 \mathrm{mV}$ more negative at $30 \mathrm{hr}$ than at $4 \mathrm{hr}$ (Fig. 3A). A negative shift in the activation threshold of the delayed rectifier potassium current has also been observed during the development of cleavage-arrested muscle-lineage blastomeres from ascidian embryos (Shidara and Okamura, 1991). $I_{\mathrm{K}}$ also becomes more rapidly inactivating at later times (Fig. 1; Spruce and Moody, 1992), consistent with the inactivating nature of the delayed rectifier current in mature muscle (Stanfield, 1970).

The inwardly rectifying potassium current $\left(I_{\mathrm{IR}}\right)$ appears about the same time as $I_{K}$, and its development shows a similar time course to that of $I_{\mathrm{K}}$ (Figs. 1, 2). $I_{\mathrm{IR}}$ density increases steadily up to $14 \mathrm{hr}$, decreases slightly between 14 and $22 \mathrm{hr}$. and then begins to increase again. $I_{\mathrm{IR}}$ shows no change in kinetics or voltage dependence during its development (Figs. 1, 3B).

Two additional depolarization-activated currents appear around $8 \mathrm{hr}$ - a fast inward sodium current $\left(I_{\mathrm{Na}}\right)$ and a transient, A-type potassium current $\left(I_{\mathrm{A}} ;\right.$ Fig. 1). The expression of these two transient currents appears to be very well correlated temporally. Between 8 and $10 \mathrm{hr}, I_{\mathrm{N}: \mathrm{i}}$ was identified in $41 \%$ of cells examined (23 of 56) and $I_{\mathrm{A}}$ in $37 \%$ (21 of 56); during this period of time, $I_{\mathrm{A}}$ was observed in $74 \%$ ( 17 of 23 ) of cells expressing 


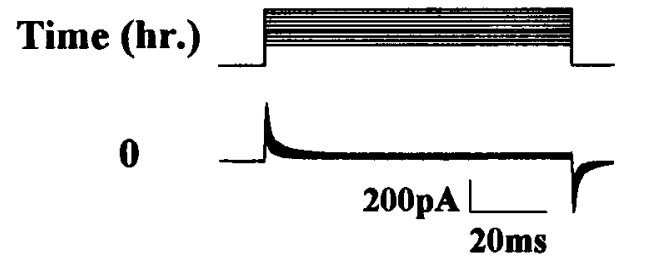

4

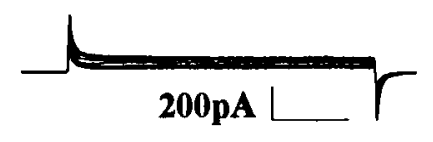

6

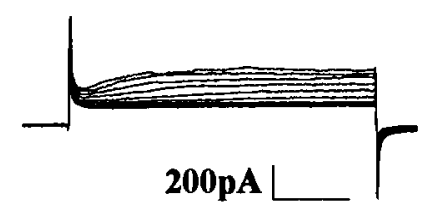

8

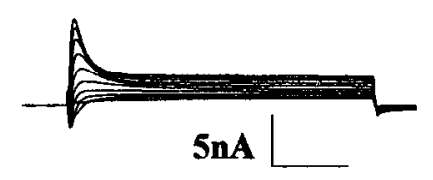

24

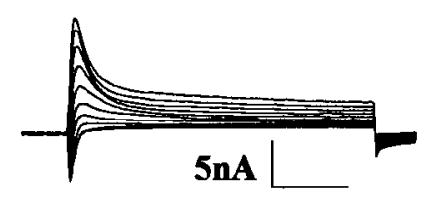

30

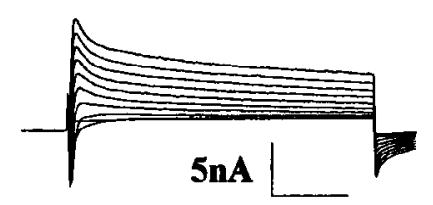

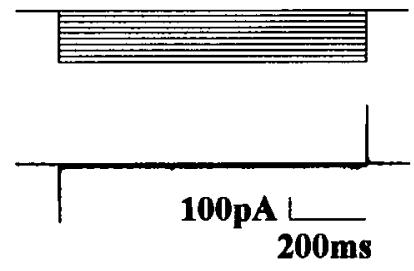
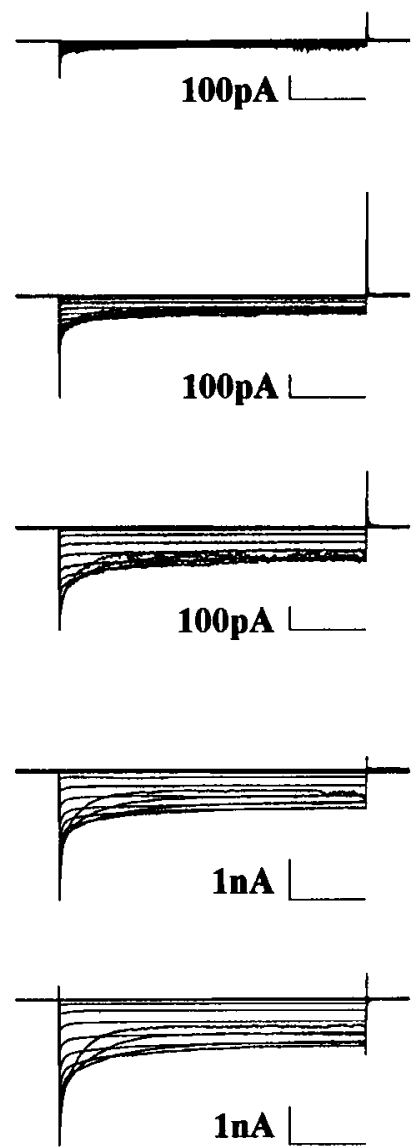

Figure 1. Devclopment of voltagegated potassium and sodium currents in embryonic Xenopus myocytes. Currents were activated by depolarizing (left) or hyperpolarizing ( $r i g h t$ ) voltage steps, in cells $0,4,6,8,24$, and $30 \mathrm{hr}$ after stage 15 ( far left). Note the different current scales used at different stages; the time scales for depolarizing and hyperpolarizing pulses are the same at all stages. Depolarizing voltage pulses were from a holding potential of $-100 \mathrm{mV}$ to between -50 and +40 $\mathrm{mV}$; hyperpolarizing pulses were from a holding potential of $-60 \mathrm{mV}$ to bctween -60 and $-150 \mathrm{mV}$.
$I_{\mathrm{Ni}}$, compared with $12 \%$ (4 of 33) of cells with no $I_{\mathrm{Na}} . I_{\mathrm{A}}$ is not a sodium-activated potassium current, however, since it is unaffected by blocking $I_{\mathrm{N}_{\mathrm{a}}}$ with TTX (not shown). In contrast with the development of $I_{\mathrm{K}}$ and $I_{\mathrm{IR}}, I_{\mathrm{N} \text { it }}$ increases steadily from the time at which it is first observed until 26 hr. Thus, between 14 and $18 \mathrm{hr}$, the densities of both $I_{\mathrm{K}}$ and $I_{\mathrm{IR}}$ are decreasing, while $I_{\mathrm{N} i}$ density continues to increase, raising the possibility that electrical excitability may be increasing over this period.

Embryonic Xenopus myocytes also express a dihydropyridine-sensitive voltage-gated calcium current with properties similar to those seen in adult muscle (Moody-Corbett et al., 1989); however, the early developmental profile of this current has not been investigated. The development of barium currents through calcium channels $\left(I_{\mathrm{Ca}}\right)$ is shown in Figure $4 . I_{\mathrm{Ca}}$ is acquired by most cells around $10-12 \mathrm{hr}$, and was identified in almost all cells (40 of 41 ) from $16 \mathrm{hr}$ onwards. As with $I_{\mathrm{Na}}, I_{\mathrm{Ca}}$ density appears to increase steadily during development.

Effects of blocking sodium and calcium channel activity on voltage-gated current expression

The expression of $I_{\mathrm{K}}$ at late times in these cells is partly dependent on electrical activity, as it can be reduced by culturing myocytes in the presence of TTX (Linsdell and Moody, 1994). To determine the effects of electrical activity on the different phases of $I_{\mathrm{K}}$ development identified in Figure $2 A$, we made whole-cell recordings between 0 and $30 \mathrm{hr}$ from myocytes cultured in the continuous presence of TTX (see Materials and Methods). TTX had no effect on $I_{\mathrm{K}}$ until $12 \mathrm{hr}$ (Fig. 5A), shortly after the time of acquisition of $I_{\mathrm{Na}}$ in most cells (Fig. 2C), strongly suggesting that the effects of TTX are due to block of $I_{\mathrm{Na}} \cdot I_{\mathrm{K}}$ density was significantly less in TTX-cultured myocytes than controls at $12-14 \mathrm{hr}$ and $20-26 \mathrm{hr}(p<0.05$, one-tailed $t$ test; Fig. 5A). Removal of TTX from older cultures had no effect on $I_{\mathrm{K}}$ density (not shown), indicating that this current is insensitive to either sodium entry or to TTX itself. Although TTX culture greatly reduces the density of $I_{\mathrm{K}}$, it does not seem to affect the normal developmental change seen in $I_{\mathrm{K}}$ voltage dependence (Fig. 6). This suggests that TTX reduces the overall level of expression of functional potassium channels, rather than specifically preventing the appearance of a more mature type of channel.

Following complete TTX removal, it was also observed that $I_{\mathrm{N}: \mathrm{l}}$ density was significantly less than in myocytes cultured in 


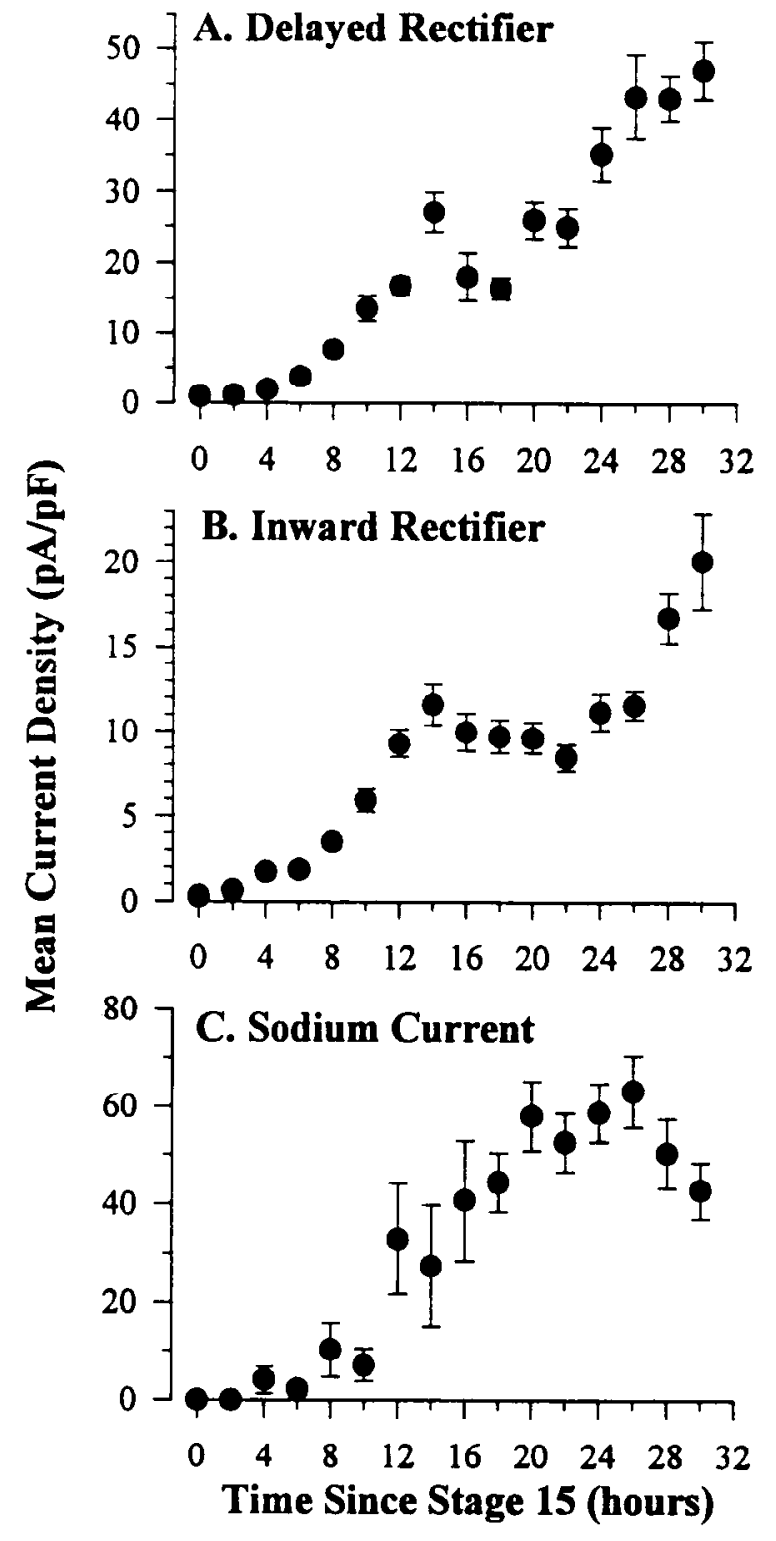

\section{$\begin{array}{lllllll}15 & 21 & 25 & 28 & 31 & 33 & 35\end{array}$ Approximate Stage in vivo}

Figure 2. Developmental time course of $I_{\mathrm{K}}(A), I_{\mathrm{IR}}(B)$, and $I_{\mathrm{Na}}(C)$. Each point represents the mean \pm SEM (where this is larger than the size of the symbol) of data from 13-37 cells, grouped into $2 \mathrm{hr}$ bins relative to stage 15 . Also shown are the approximate in vivo stages (Nieuwkoop and Faber, 1967) corresponding to different times after stage 15. Current densities were calculated as described previously (see Materials and Methods).

the absence of TTX (Fig. 7). To ensure all TTX was effectively removed from the external solution following thorough washing, control Danilchik's medium was also applied directly to cells from a nearby perfusion pipette during recording. $I_{\mathrm{Na}}$ amplitude following perfusion of TTX-free Danilchik's medium was 101.1 $\pm 8.8 \%$ of that before perfusion (but after washing; $n=8$ ), indicating that all TTX had already been effectively removed by washing. Thus, it appears that culturing these muscle cells in the presence of TTX reduces the functional expression of $I_{\mathrm{Na}}$, suggesting that electrical activity during early myogenesis increases the expression of $I_{\mathrm{N} i \mathrm{l}}$ as well as $I_{\mathrm{K}}$.
TTX had no effect on the development of $I_{\mathrm{IK}}$ (Fig. $5 \mathrm{~B}$; Linsdell and Moody, 1994). The density of $I_{\mathrm{C} a}$ in older myocytes was also unaffected by culturing in the presence of $1 \mu \mathrm{M}$ TTX; between 22 and $28 \mathrm{hr}$, mean $I_{\mathrm{Ca}}$ density was $1.16 \pm 0.15 \mathrm{pA} /$ $\mathrm{pF}(n=22)$ in control cells and $1.13 \pm 0.15 \mathrm{pA} / \mathrm{pF}(n=25)$ in TTX-cultured cells. Thus, $I_{\mathrm{Na}}$-mediated electrical activity appears not to regulate either $I_{\mathrm{IR}}$ or $I_{\mathrm{c} \text { a }}$ development.

Because many of the reported effects of electrical activity on muscle properties appear to involve calcium entry through voltage-gated channels (Smilowitz et al., 1988; Brodie et al., 1989; Klarsfeld et al., 1989; Huang et al., 1994), we also tested the effects of the calcium channel blocker nifedipine on potassium and sodium current development. Culturing myocytes in the presence of nifedipine reduced the development not only of $I_{\mathrm{K}}$ and $I_{\mathrm{Na}}$, but also to a lesser extent $I_{\mathrm{IK}}$ (Fig. 8). The similar effects of TTX and nifedipine on the development of $I_{\mathrm{K}}$ and $I_{\mathrm{Na}}$ suggest that the effects of electrical activity on these two currents are mediated via activation of voltage-gated calcium channels. The fact that $I_{\mathrm{IR}}$ expression is reduced hy nifedipine but not by TTX suggests that, even when electrical activity is blocked, sufficient calcium entry occurs to fully stimulate development of this current.

Culturing myocytes in the presence of dantrolene, which blocks calcium efflux from internal stores, did not mimic the effects of nifedipine on the expression of either $I_{\mathrm{K}}$ or $I_{\mathrm{Ni}}$ (data not shown), suggesting that the effects of calcium entry through voltage-gated channels are not mediated by calcium-dependent calcium release from internal stores. This contrasts with the calcium-dependent differentiation of Xenopus spinal neurons, which is disrupted by depletion of internal calcium stores (Holliday et al., 1991). Acetylcholine receptor gene expression in the mouse muscle cell line $\mathrm{C} 2 \mathrm{C} 12$ is regulated by calcium entry lirough vollage-gated channels, but not by calcium released from internal stores (Huang et al., 1994).

\section{Discussion}

Development of the Xenopus embryo is very rapid, with spontaneous movements beginning around $30 \mathrm{hr}$ after fertilization. This rate of development is reflected in the rapidly changing electrophysiological properties of cultured embryonic myocytes. Under our culture conditions, these cells acquire $I_{\mathrm{K}}, I_{\mathrm{IK}}, I_{\mathrm{A}}, I_{\mathrm{Na}}$, and $I_{\mathrm{Ca}}$ over a period of about $12 \mathrm{hr}$, thereby developing from a state of having no voltage-gated currents to one of having a similar complement of currents to those seen in adult muscle. These cultured cells also first begin to show contractions in response to application of high concentrations of potassium or depolarizing pulses applied through the patch pipette around 12 hr after stage 15 , or $30 \mathrm{hr}$ after fertilization (P. Linsdell, unpublished observations), suggesting that electrical development in culture approximates that in vivo.

Although the electrical development of these cells is characterized by dramatic increases in potassium and sodium current densities (Fig. 3), perhaps more intriguing is the decrease in potassium current densities that occur between 14 and $18 \mathrm{hr}$ for $I_{\mathrm{K}}$, and between 14 and $22 \mathrm{hr}$ for $I_{\mathrm{IR}}$. Over the same period of time, $I_{\mathrm{Na}}$ density continues to increase; for example, between 14 and $18 \mathrm{hr}$, mean $I_{\mathrm{Na}}$ density increases by $62 \%$, while mean $I_{\mathrm{K}}$ density decreases by $39 \%$ and mean $I_{\mathrm{IR}}$ density decreases by $16 \%$. Although the relative densities of these currents are not the sole determinants of the state of electrical excitability, it is possible that these changes in current densities allow for a brief 


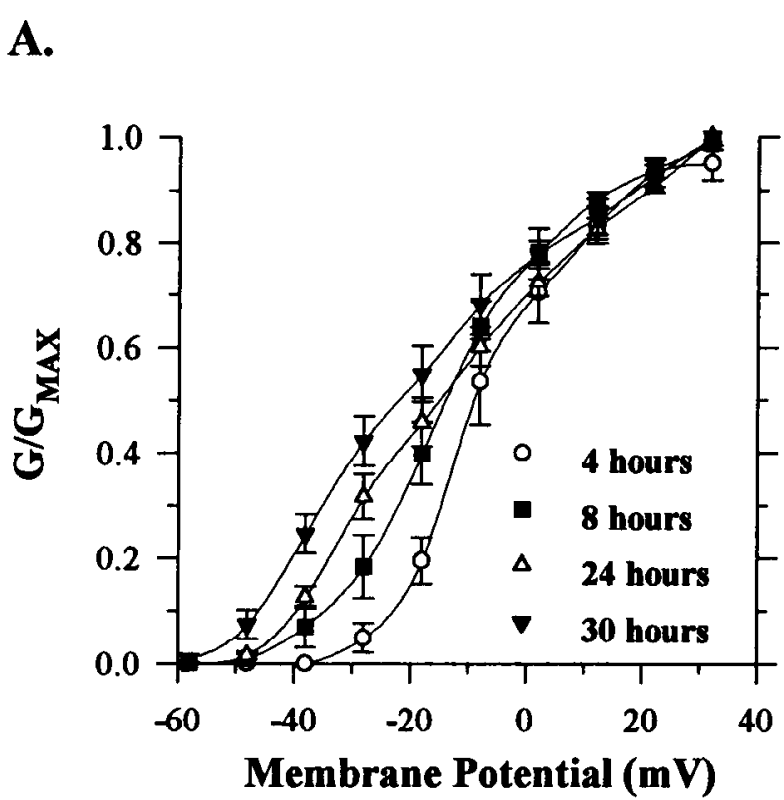

\section{B. Membrane Potential (mV)}
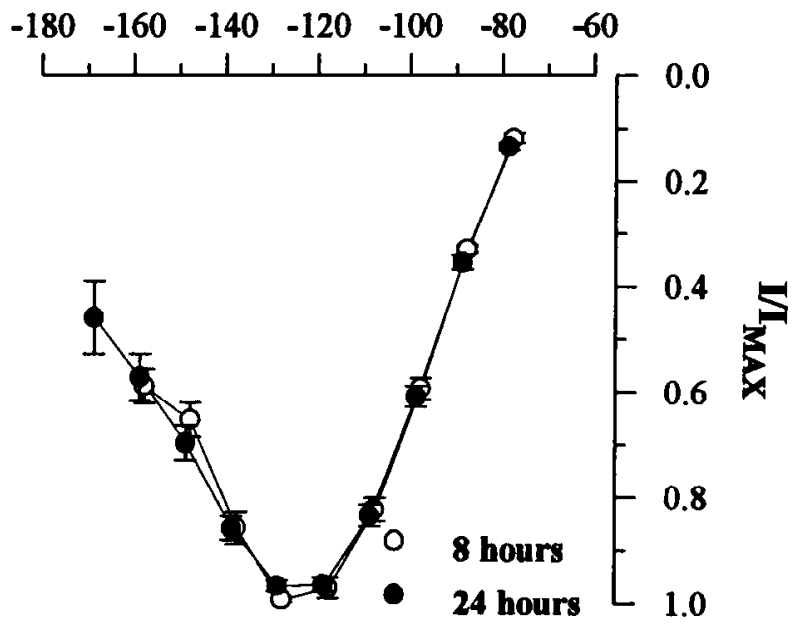

Figure 3. Voltage dependence of $I_{\mathrm{K}}(A)$, and $I_{\mathrm{IR}}(B)$ at different developmental times. $A$. Mean conductance-voltage relationship for $I_{\mathrm{K}}$ at 4 , 8 , 24 , and $30 \mathrm{hr}$, constructed using data from 7-13 cells at each stage. Current amplitudes were measured as described in Materials and Methods and used to calculate relative conductances using a calculated potassium cquilibrium potential of $-75 \mathrm{mV}$. $B$, mean steady-state current-voltage relationship for $I_{\mathrm{IR}}$ at 8 and $24 \mathrm{hr}$ after stage 15 , constructed using data from 5-16 cells at each stage. In both $A$ and $B$, error bars represent \pm SEM, where this is larger than the size of the symbol.

period in the development of these myocytes during which electrical activity is increased.

The developmental time course of $I_{\mathrm{K}}$ in the presence of TTX (Fig. 5A) does, indeed, suggest a key role for electrical activity around this time. The largest effect of TTX on $I_{K}$ occurs between 20 and $26 \mathrm{hr}$ (Fig. 5A), shortly following the suggested period of increased activity outlined above. At later times, $I_{\mathrm{K}}$ densities in control and TTX-cultured myocytes are more similar, suggesting that at these times electrical activity plays no role in controlling $I_{\mathrm{K}}$ expression. However, this "catching up" of $I_{\mathrm{K}}$ density at late times does not occur in cells cultured in the presence of nifedipine (Fig. 8A). In fact, nifedipine appears to prevent the secondary increases in both $I_{\mathrm{K}}$ and $I_{\mathrm{IR}}$ density (Fig. $8 A, B)$. This apparent anomaly between the effects of TTX and nifedipine suggests that at later developmental times, $I_{\mathrm{C} \text { il }}$ density is large enough to allow sufficient calcium entry to stimulate $I_{\mathrm{K}}$ and $I_{\mathrm{IR}}$ expression even in the absence of $I_{\mathrm{Na}}$-induced electrical activity. The effects of electrical activity at earlier times seem certain to be mediated via activation of voltage-gated calcium channels; TTX and nifedipine have similar effects on the expression of $I_{\mathrm{K}}, I_{\mathrm{lR}}$, and $I_{\mathrm{Na}}$, and the onset of TTX-sensitivity of $I_{\mathrm{K}}$ expression occurs around the time of acquisition of $I_{\mathrm{Ca}}$ (Figs. 4, 5A).

Cultured Xenopus muscle cells do not exhibit spontaneous contractions, suggesting that aneurally cultured myocytes are not spontaneously active. It is unclear therefore how sodium and calcium channel activities are linked. It is possible that at early developmental stages such as those examined here, these cells could exhibit spontaneous activity that is subthreshold for action potential generation, or that single action potentials may be in-
A.

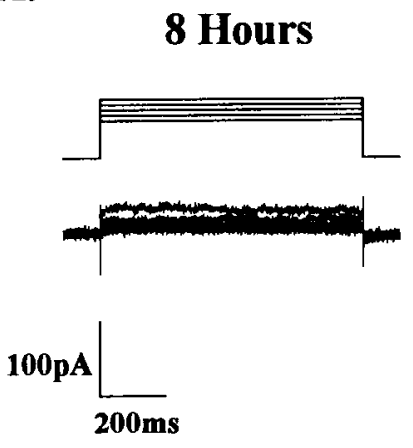

24 Hours

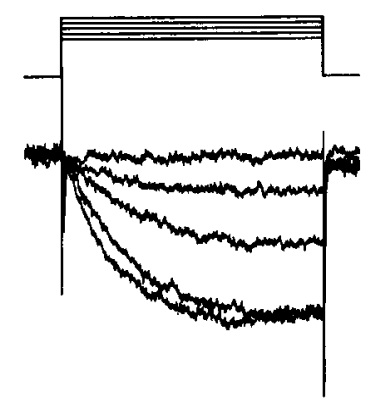

B.

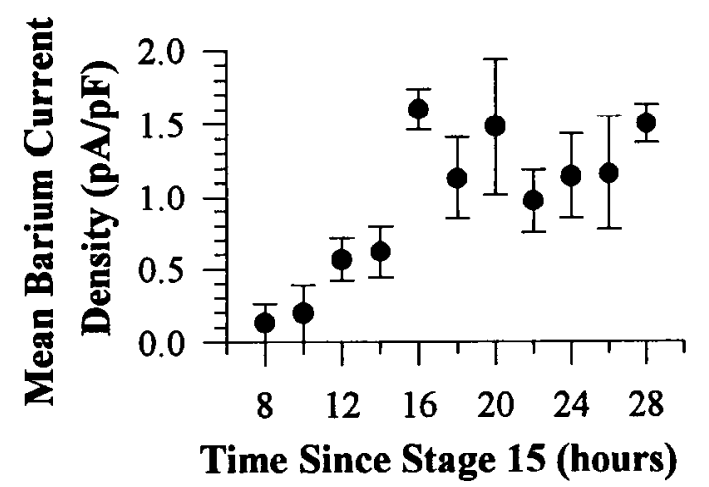

Figure 4. Development of barium currents. A, Currents activated by depolarizing steps from a holding potential of $-100 \mathrm{mV}$ to between -30 and $+10 \mathrm{mV}$ in cells 8 (left) and 24 (right) hr after stage 15. Barium currents (carried through calcium channels; $I_{(\mathrm{i})}$ ) were isolated as deseribed in Materials and Methods. $B$, developmental time course of $I_{C \rightarrow}$. Each point represents mean $\pm \operatorname{SEM}(n=4-11)$. Current densities were calculated as described previously (see Materials and Methods). 

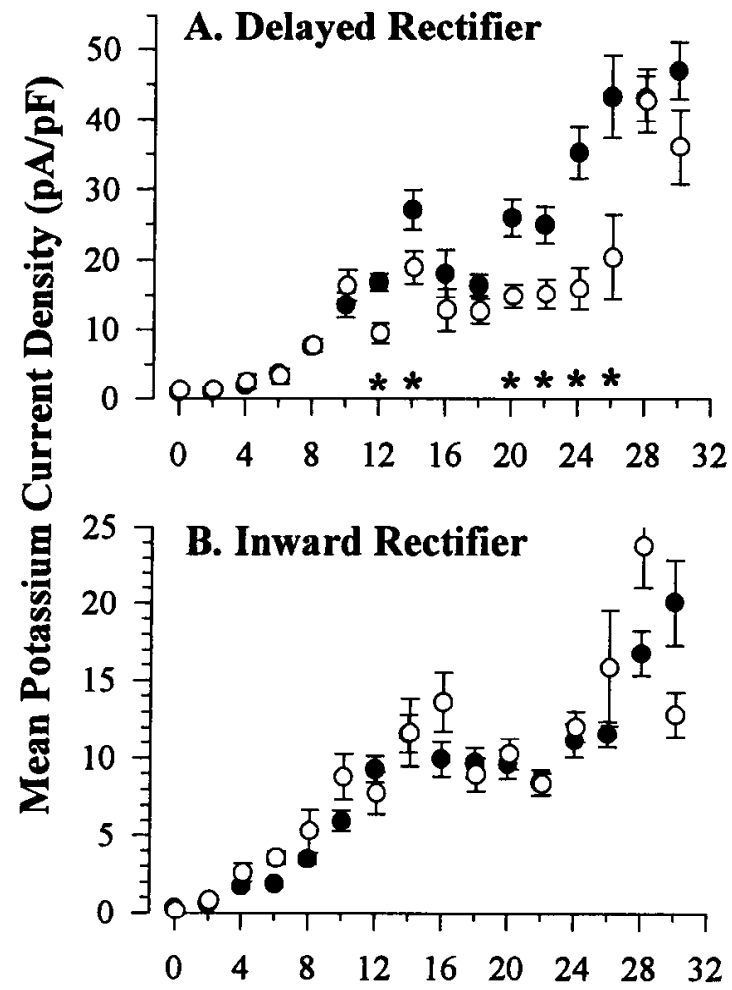

Time Since Stage 15 (hours)

Figure 5. Effect of culturing in TTX on the development of $I_{\mathrm{K}}(A)$ and $I_{\mathrm{IR}}(B)$. In both $A$ and $B$, filled circles represent control cells and open circles cells cultured in the presence of $1 \mu \mathrm{M}$ TTX. Data is shown as mean \pm SEM (where this is larger than the size of the symbol) from 13-36 control cells and 5-16 TTX-cultured cells. *Represents those time points at which mean current density is significantly less in TTXcultured than in control cells $(\mu<0.05$, one-tailed $t$ test $)$.

sufficient to initiate contraction. Alternatively, since we find that both $I_{\mathrm{Na}}$ (Fig. $2 C$ ) and $I_{\mathrm{Ca}}$ (Fig. $4 B$ ) are present before the cells become contractile (around $12 \mathrm{hr}$ after stage 15; see above), it may be that spontaneous activity occurs before the development of excitation-contraction coupling.

The development of $I_{\mathrm{K}}$ and $I_{\mathrm{R}}$ in the presence of nifedipine (Fig. 8A,B) suggest that the two apparent phases of potassium current expression (see Fig. $2 A, B$ ) are functionally separable components, since the secondary increase in each current (beginning around $20 \mathrm{hr}$ for $I_{\mathrm{K}}$ and $24 \mathrm{hr}$ for $I_{\mathrm{TR}}$ ) is effectively abolished in the presence of nifedipine. We suggest that the development of voltage-gated potassium currents by these myocytes is controlled by two separate, sequential programs of functional channel expression, the first $(0-14 \mathrm{hr})$ being intrinsic to the muscle cells, and the second being stimulated by calcium influx. However, even the "intrinsic" program is sensitive to electrical activity, since the earliest expression of $I_{\mathrm{K}}$ and $I_{\mathrm{IR}}(0-$ $8 \mathrm{hr}$ ) can be stimulated by increased electrical activity following sodium channel misexpression (Linsdell and Moody, 1994). The mechanism linking electrical activity with this early phase of potassium current expression is unknown, since we have no evidence for the presence of functional calcium currents in these cells before $8 \mathrm{hr}$

The electrical activity-dependent expression of $I_{\mathrm{K}}$ in these cells has previously been suggested to provide a compensatory feedback mechanism to control membrane excitability (Linsdell and Moody, 1994). However, electrical activity also appears to

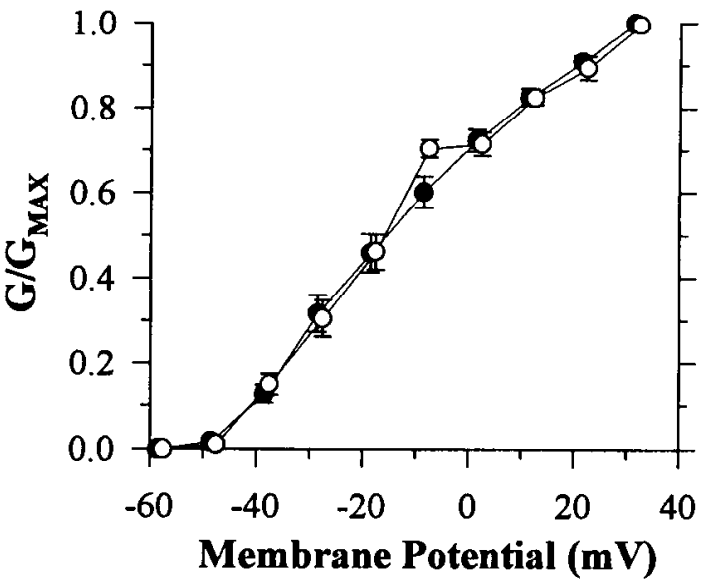

Figure 6. Culturing in TTX does not alter the voltage dependence of $I_{\mathrm{k}}$. Mean conductance-voltage relationships were corstrucled as described in the legend to Figure 2, for control cells (filled circles; $n=$ 13) and TTX-cultured cells (open circles; $n=8$ ), both measured $24 \mathrm{hr}$ after stage 15. Culturing in IIIX also had no effect on the voltage dependence of $I_{\mathrm{K}}$ measured at other times (not shown).

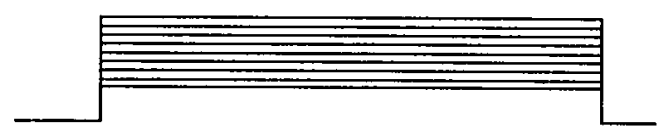

\section{Control}

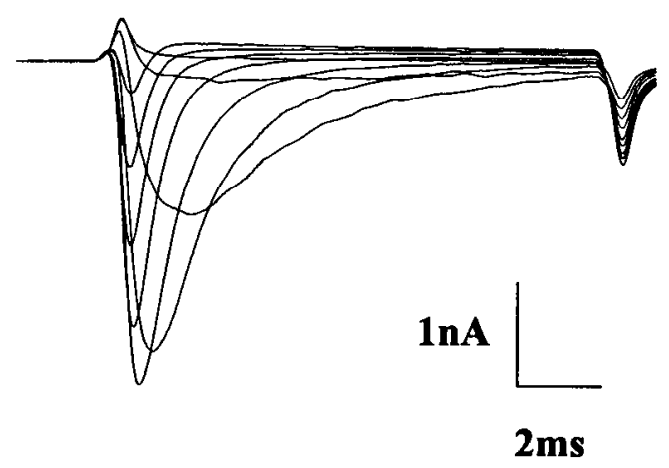

TTX Cultured

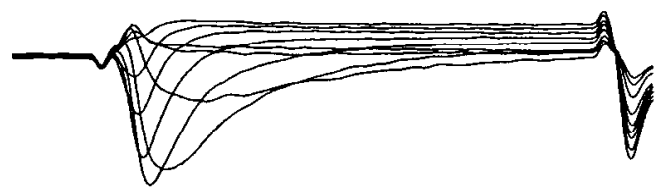

Figure 7. Culturing in TTX reduces the expression of $I_{\mathrm{N} \text {. }}$. Sodium currents recorded $24 \mathrm{hr}$ after stage 15 from a control cell (top) and from a cell cultured in the presence of $1 \mu \mathrm{M}$ TTX (bottom), with the TTX removed just prior to recording (see text). Direct application of TTXfree solution to this cell did not lead to any further increase in $I_{\mathrm{Na}_{\mathrm{a}}}$, indicating that all TTX had been effectively removed and that the level of sodium channel expression had been reduced by TTX culture. Holding potential $-100 \mathrm{mV}$; voltage steps to between -60 and $+20 \mathrm{mV}$. 


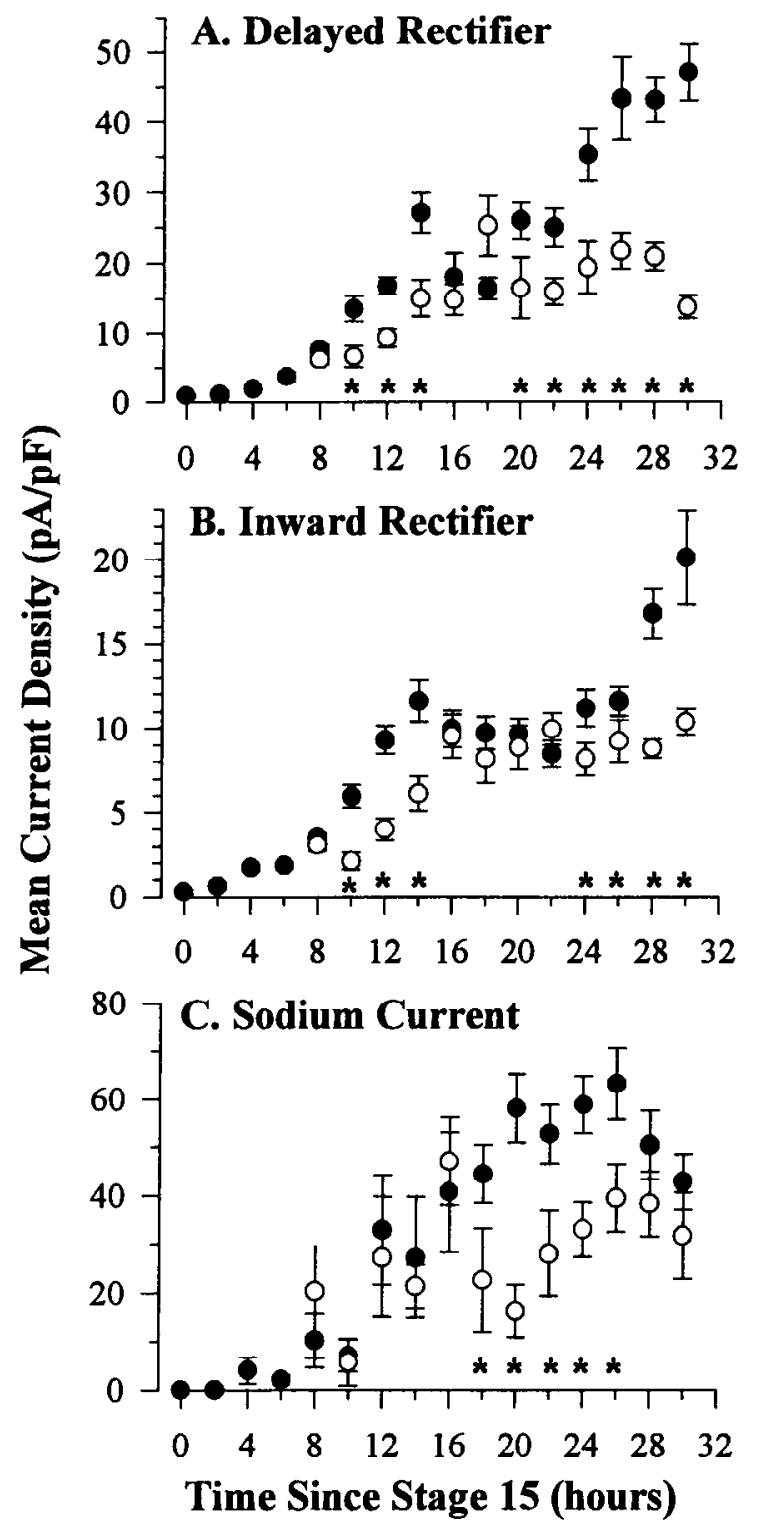

Figure 8. Effect of culturing in the nifedipine on the development of $I_{\mathrm{K}}(A), I_{\mathrm{IR}}(B)$, and $I_{\mathrm{N} \mathrm{a}}(C)$. In each case, filled circles represent control cclls and open circles cells cultured in the presence of $10 \mu \mathrm{M}$ nifedipine. Data is shown as mean \pm SEM (where this is larger than the size of the symbol) from 13-37 control cells and 3-15 nifedipine cultured cells. * Represents those time points at which mean current density is significantly less in nifedipine-cultured cells than in control cells $(p<0.05$, one-tailed $t$ test)

increase the expression of $I_{\mathrm{N} \text { al }}$ (Fig. 7), which would be expected to constitute a positive feedback mechanism. This unexpected finding contrasts with previous reports on the effects of electrical activity on the expression of sodium channels in mammalian skeletal muscle (Sherman and Catterall, 1984; Bar-Sagi and Prives, 1985; Brodie et al., 1989; Offord and Catterall, 1989) and neurons (Dargent and Couraud, 1990). The presence of such a positive feedback system might allow a very rapid increase in $I_{\mathrm{N}:}$ density, which may be important in driving other activitydependent developmental processes and so ensuring muscle development proceeds as quickly as possible.

Our results indicate that electrical activity and calcium influx play a key role in ion channel development in embryonic Xenopus myocytes. We suggest that the initial acquisition of voltage- gated sodium and calcium channels, possibly coupled with a decrease in potassium current density, lead to an increase in electrical activity and thus an increase in voltage-gated calcium influx. The earliest appearance of these two channel types would therefore seem to signal the beginning of a critical period in the electrical development of these cells.

In vivo, innervation of embryonic Xenopus mesoderm begins around 5-6 hr after stage 15 (approximately stage 21-22), causing an almost immediate increase in both electrical activity (Evers et al., 1989) and intracellular calcium concentration (Zhu and Peng, 1988) in the postsynaptic cell, which, according to our findings, should profoundly influence muscle ion channel development. However, our results on aneurally cultured muscle cells indicate that muscle cells also have their own intrinsic patterns of electrical development, and are not merely the passive recipients of nerve-induced electrical activity.

\section{References}

Bar-Sagi D, Prives J (1985) Negative nodulation of sodiun channels in cultured chick muscle cells by the channel activator batrachotoxin. J Biol Chem 260:4740-4744.

Bixby JL, Spitzer NC (1984) Early differentiation of vertebrate spinal neurons in the absence of voltage-dependent $\mathrm{Ca}^{2+}$ and $\mathrm{Na}^{+}$influx. Dev Biol 106:89-96.

Brevet A, Pinto E, Peacock J, Stockdale FE (1976) Myosin synthesis increased by electrical stimulation of skeletal muscle cell cultures. Science 193:1152-1154

Broadie KS, Bate M (1993) Development of larval muscle properties in the embryonic myotubes of Drosophila melanogaster. J Neurosci 13:167-180.

Brodie C, Brody M, Sampson SR (1989) Characterization of the relation between sodium channels and electrical activity in cultured rat skeletal myotubes: regulatory aspects. Brain Res 488:186-194.

Buonanno A, Apone L, Morasso MI, Beers R, Brenner HR, Eftimie R (1992) The MyoD family of myogenic factors is regulated by electrical activity: isolation and characterization of a mouse Myf-5 cDNA. Nucleic Acids Res 20:539-544.

Chahine KG, Baracchini E, Goldman D (1993) Coupling muscle electrical activity to gene expression via a cAMP-dependent second messenger system. J Biol Chem 268:2893-2898.

Dargent B, Couraud F (1990) Down-regulation of voltage-dependent sodium channels initiated by sodium influx in developing neurons. Proc Natl Acad Sci USA 87:5907-5911.

Eftimie R, Brenner HR, Buonanno A (1991) Myogenin and MyoD join a family of skeletal muscle genes regulated by electrical activity. Proc Natl Acad Sci USA 88:1349-1353.

Evers J, Laser M, Sun Y-A, Xie Z-P, Poo M-M (1989) Studies of nerve-muscle interactions in Xenopus cell culture: analysis of early synaptic currents. J Neurosci 9:1523-1539.

Fontaine B, Klarsfeld A, Changeux J-P (1987) Calcitonin gene-related peptide and muscle activity regulate acetylcholine receptor $\alpha$-subunit mRNA levels by distinct intracellular pathways. J Cell Biol 105: 1337-1342.

Freud-Silverberg M, Shainberg A (1993) Electric stimulation regulates the level of Ca-channels in chick muscle culture. Neurosci Lett 151: 104-106.

Goldman D, Brenner HR, Heinemann S (1988) Acetylcholine receptor $\alpha-, \beta-, \gamma$, and $\delta$-subunit mRNA levels are regulated by muscle activity. Neuron 1:329-333.

Hahn C-G, Couvault J (1992) Neural regulation of N-cadherin gene expression in developing and adult skeletal muscle. J Neurosci 12: $4677-4687$.

Hamill OP, Marty A, Neher E, Sakmann F, Sigworth FJ (1981) Improved patch-clamp techniques for high-resolution current recording from cells and cell-free membrane patches. Pfluegers Arch 391:85100.

Heathcote RD (1989) Acetylcholine-gated and chloride conductance channel expression in rat muscle membrane. J Physiol (Lond) 414: 473-497.

Holliday J, Spitzer NC (1990) Spontaneous calcium influx and its roles in differentiation of spinal neurons in culture. Dev Biol 141:13-23. 
Holliday J, Adams RJ, Sejnowski TJ, Spitzer NC (1991) Calciuminduced release of calcium regulates differentiation of cultured spinal neurons. Neuron 7:787-796.

Huang C-F, Tong J, Schunidt J (1992) Protein kinase C couples membrane excitation to acetylcholine receptor gene inactivation in chick skeletal muscle. Neuron 9:671-678.

Huang C-F, Neville CM, Schmidt J (1993) Control of myogenic factor genes by the membrane depolarization/protein kinase $\mathrm{C}$ cascade in chick skeletal muscle. FEBS Lett 319:21-25.

Huang C-F, Flucher BE, Schmidt MM, Stroud SK, Schmidt J (1994) Depolarization-transcription signals in skeletal muscle use calcium flux through $L$ channels, but bypass the sarcoplasmic reticulum. Neuron $13: 167-177$

Jones SM, Ribera AB (1994) Overexpression of a potassium channel gene perturbs neural differentiation. J Neurosci 14:2789-2799.

Keller RE, Danilchik M, Gimlich R, Shih J (1985) The function and mechanism of convergent extension during gastrulation of Xenopus laevis. J Embryol Exp Morphol [Suppl] 89:185-209.

Klarsfeld A, Changeux J-P (1985) Activity regulates the levels of acetylcholine receptor $\alpha$-subunit mRNA in cultured chicken myotubes. Proc Natl Acad Sci USA 82:4558-4562.

Klarsfeld A, Laufer R, Fontaine B, Devillers-Thièry A, Dubreuil C, Changeux J-P (1989) Regulation of muscle $\mathrm{AChR} \alpha$ subunit gene expression by electrical activity: involvement of protein kinase $\mathrm{C}$ and $\mathrm{Ca}^{2+}$. Neuron 2:1229-1236.

Linsdell P, Moody WJ (1994) $\mathrm{Na}^{+}$channel misexpression accelerates $\mathrm{K}+$ channel development in embryonic Xenopus laevis skeletal muscle. J Physiol (Lond) 480:405-410.

Lyles JM, Amin W, Bock E, Weill CL (1993) Regulation of NCAM by growth factors in serum-free myotube cultures. J Neurosci Res $34: 273-286$

Moody WJ, Simoncini L, Coombs JL, Spruce AE, Villaz M (1991) Development of ion channels in early embryos. J Neurobiol 22:674684.

Moody-Corbett F, Gilbert R, Akbarali H, Hall J (1989) Calcium current in embryonic Xenopus muscle cells in culture. Can J Physiol Pharmacol 67:1259-1264.

Morgan KG, Bryant SH (1977) The mechanism of action of dantrolene sodium. J Pharmacol Exp Ther 201:138-147

Neville CM. Schmidt M, Schmidt J (1992) Response of myogenic determination factors to cessation and resumption of electrical activ- ity in skeletal muscle: a possible role for myogenin in denervation supersensitivity. Cell Mol Neurobiol 12:5 I l-527.

Nieuwkoop PD, Faber J (1967) Normal table of Xenopus laevis (Daudin . Amsterdam: North-Holland.

Offord J, Catterall WA (1989) Electrical activity, CAMP, and cytosolic calcium regulate mRNA encoding sodium channel $\alpha$ subunits in rat lfuscle cells. Neuron 2:1447-1452.

Ribera AB, Spitzer NC (1991) Differentiation of delayed rectifier potassium current in embryonic amphibian myocytes. Dev Biol 144: $119-128$.

Ribera AB, Spitzer NC (1992) Developmental regulation of potassium channels and the impact on neuronal differentiation. In: Ion channels, Vol 3 (Narahashi T, ed), pp 1-38. New York: Plenum.

Rubin LL (1985) Increases in muscle $\mathrm{Ca}^{2+}$ mediate changes in acetylcholinesterase and acetylcholine receptors caused by muscle contraction. Proc Natl Acad Sci USA 82:7121-7125.

Sherman SJ, Catterall WA (1984) Electrical activity and cytosolic calcium regulate levels of tetrodotoxin-sensitive sodium channels in cultured rat muscle cells. Proc Natl Acad Sci USA 81:262-266.

Sherman SJ, Chrivia J, Catterall WA (1985) Cyclic adenosine $3^{\prime}: 5^{\prime}-$ monophosphate and cytosolic calcium exert opposing effects on biosynthesis of tetrodotoxin-sensitive sodium channels in rat muscle cells. J Neurosci 5:1570-1576.

Shidara M, Okamura Y (1991) Developmental changes in delayed rectifier $\mathrm{K}^{+}$currents in the muscular- and neural-type blastomere of ascidian embryos. J Physiol (Lond) 443:277-305.

Smilowitz H, Smart E, Bowik C, Chang R-J (1988) Regulation of the number of $\alpha$-bungarotoxin binding sites in cultured chick myotubes by a 1,4 dihydropyridine calcium channel antagonist. J Neurosci Res 19:321-325.

Spitzer NC (1991) A developmental handshake: neuronal control of ionic currents and their control of neuronal differentiation. J Neurobiol 22:659-673.

Spruce AE, Moody WJ (1992) Developmental sequence of expression of voltage-dependent currents in embryonic Xenopus laevis myocytes. Dev Biol 154:11-22.

Stanfield PR (1970) The effect of the tetraethylammonium ion on the delayed currents of frog skeletal muscle. J Physiol (Lond) 209:209229.

Zhu D-L, Peng HB (1988) Increase in intracellular calcium induced by the polycation-coated latex bead, a stimulus that causes postsynaptic-type differentiation in cultured Xenopus muscle cells. Dev Biol $126: 63-70$ 